\title{
CHRISTIAN RELIGIOUS LEADERSHIP AND THE CHALLENGE OF SUSTAINABLE TRANSFORMATIONAL DEVELOPMENT IN POST-MILITARY NIGERIA: TOWARDS A REAPPRAISAL ${ }^{1}$
}

Author:

Dr. Obaji M. Agbiji ${ }^{1}$

Prof. Ignatius Swart ${ }^{1}$

\begin{abstract}
Affiliation:
${ }^{1}$ Research Institute for Theology and Religion

University of South Africa
\end{abstract}

\section{Correspondence to:}

Dr. Obaji M. Agbiji

Email:

obajiagbiji@gmail.com

Correspondence to:

Prof. Ignatius Swart

Email:

swarti1@unisa.ac.za

Postal address:

PO Box 329 Pretoria, 0003, South Africa

Dates:

Accepted: 01 Jun. 2015 Published: 01 Sep. 2015

How to cite this article: Agbiji, O. M. \& Swart, I., 2015, 'Christian religious leadership and the challenge of sustainable transformational development in postmilitary Nigeria: Towards a reappraisal' KOERS - Bulletin for Christian Scholarship 80(1), Art. \#2212, 13 pages. http:// dx.doi.org/10.19108/ koers.80.1.2212

\section{Copyright:}

(c) 2015. The Author(s).

Published under the

Creative Commons

Atribution License.
This article seeks to make an initial contribution towards a reappraisal of how the Christian religious leadership in Nigeria is beginning to chart a new course in social transformation that has the potential to engender sustainable transformational development in the country. This aim is met by first providing the necessary contextual orientation of how the two broad areas of political governance and economic development present themselves as prevailing major social challenges in present-day post-military Nigeria. This is followed by a discussion of the role of leadership as a primary causal and redeeming factor in meeting the challenge of sustainable transformational development both in Nigeria and African society at large. The authors proceed then towards the main focus of the article, namely to move - on the basis of a literature and empirical exploration towards a reappraisal of how the Christian religious leadership in present-day Nigeria is beginning to exert itself as an emerging movement for sustainable transformational development through particular institutional arrangements and modes of social engagement. This reappraisal leads the authors to end with a synthesising reflection on what they consider to be not only the most outstanding contribution to date by the Christian religious leadership in present-day Nigeria in advancing a sustainable transformational development agenda, but also the crucial challenges that this leadership still faces in meeting such an agenda.

Keywords: Christian religious leadership, post-military Nigeria, sustainable transformational development, leadership, African societies, political governance, economic development, Christian Association of Nigeria (CAN)

Hierdie artikel poog om 'n eerste bydrae te maak tot ' $\mathrm{n}$ herwaardering van die wyse waarop die Christelike godsdienstige leierskap in Nigerië besig is om ' $n$ nuwe weg te baan in sosiale transformasie wat die potensiaal het om volhoubare transformasionele ontwikkeling in dié land te bewerkstellig. Hierdie doelwit word bereik deur eerstens 'n kontekstuele oriëntering te bied van hoe die twee breë terreine van politieke staatsbestuur en ekonomiese ontwikkeling hulself as heersende sosiale uitdagings in hedendaagse post-militêre Nigerië aanbied. Dit word gevolg deur ' $\mathrm{n}$ bespreking van leierskap as ' $\mathrm{n}$ primêr oorsaaklike en bevrydende faktor in die realisering van volhoubare transformasionele ontwikkeling beide in Nigerië en die samelewing van Afrika in die breë. Hierna verskuif die bespreking na die sentrale fokus van die artikel, naamlik om op grond van 'n literatuur- en empiriese ondersoek te beweeg na 'n herwaardering van die Christelike godsdienstige leierskap as 'n ontluikende beweging vir volhoubare transformasionele ontwikkeling in hedendaagse Nigerië by wyse van spesifieke institusionele inrigtings en modusse van sosiale betrokkenheid. Hierdie herwaardering lei die skrywers daartoe om af te sluit met ' $n$ samevattende refleksie nie slegs oor wat hul beskou as die mees uitstaande bydrae tot op hede deur die Christelike godsdienstige leierskap in hedendaagse Nigerië in die bevordering van ' $n$ volhoubare transformasionele ontwikkelingsagenda nie, maar ook as die kritieke uitdagings wat dié leierskap steeds in die gesig staar in die voltrekking van sodanige agenda.

Sleutelwoorde: Christelike godsdienstige leierskap, post-militêre Nigerië, volhoubare transformasionele leierskap, Afrika-samelewings, politieke staatsbestuur, ekonomiese ontwikkeling, Christian Association of Nigeria (CAN)

$1 \quad$ This material is based upon work supported by the National Research Foundation of South Africa (NRF) under grant number 85113. Any opinion, findings and conclusions or recommendations expressed in this material are those of the authors and therefore the NRF does not accept any liability in regard thereto. 


\section{INTRODUCTION}

This article is presented as a sequel to our recent article (Agbiji \& Swart 2013) on the formation of Christian leadership ideology in Nigerian history and the implications and challenges that it poses for positive social transformation in present-day post-military or democratic Nigeria. The perspective that we developed was profoundly critical as we argued that Nigerian Christian leaders' historic inability to contribute to positive social transformation in Nigerian society was to a great extent the result of a negative leadership ideological orientation that has shaped the mind-set of Nigerian religious and political leadership for centuries (Agbiji \& Swart 2013). We therefore concluded as follows about the fundamental present-day challenge that the Christian religious leadership, as part of the leadership at large, faces in attempting to convert itself into a force for positive social transformation in present-day postmilitary Nigeria:

Nigerian religious and political leaders should be reminded that they are not simply [spiritual or] political heads [respectively]: they are the divine symbols of their people's health and wellbeing. Christian religious leadership ideology should be re-orientated towards the wellbeing of the Nigerian populace, who find themselves engulfed in poverty and deplorable living conditions. This should be seen as a sacred responsibility that should be diligently carried out. As leaders, the office is the link between human rule and spiritual rule. Christian religious leaders should re-orientate their leadership ideology and practice based on the conviction that their prophetic voice and engagement are both a social and spiritual contract for which they are accountable to God and to the people of God (Agbiji \& Swart 2013:244).

This article continues where we left the discussion in that article by focusing more pointedly on the presence of Nigeria's Christian religious leadership in the present post-military dispensation and the question of its potential and actual contribution as a transformational force. Without diverting from our critical thesis about the negative trends in the history of Christian religious leadership formation in Nigerian society (see Agbiji \& Swart 2013:221-244), in this article we argue that there may yet be some scope today to start reappraising the role and place of Christian religious leaders in the present Nigerian dispensation. Thus, whilst we maintain our position that considerable scope remains for a re-orientation of the way that Nigerian Christian religious leaders perceive and exert themselves as servants of positive social transformation (Agbiji \& Swart 2013:243-244), we at the same time find legitimate grounds on the basis of our on-going research to move towards a tentative, cautious and not uncritical reappraisal of our initial argument. Although still of an emergent nature, we proclaim that there is some evidence of a shift in Christian religious leadership that has the potential to contribute meaningfully towards our preferred notion of social transformation in this article: sustainable transformational development in presentday Nigerian society.

In our present discussion, Christian religious leadership refers to Christian clergy and other Christian leaders who occupy leadership positions in denominational and ecumenical church settings but are non-clergy. Sustainable transformational development, in turn, is defined as processes of profound and durable positive change in the spiritual, psychological, moral, social, economic, political, institutional, environmental and technological spheres (Agbiji 2012:290). Against this backdrop, this article seeks to make an initial contribution towards a reappraisal of how the Christian religious leadership in Nigeria is beginning to chart a new course in social transformation that has the potential to engender sustainable transformational development in the country. To meet our aim, we will provide the necessary contextual orientation by giving a brief account of how the two broad areas of political governance and economic development present themselves as prevailing major social challenges in present-day post-military Nigeria. This will be followed by a discussion of the role of leadership as a primary causal and redeeming factor in achieving sustainable transformational development both in Nigeria and African society at large, after which we will move - on the basis of a recent literature and empirical exploration - towards our reappraisal of how the Christian religious leadership in present-day Nigeria is beginning to exert itself as an emerging movement for sustainable transformational development through particular institutional arrangements and modes of social engagement. Finally, we will end our discussion with a synthesising reflection on what we consider to be not only the most outstanding contribution to date by the Christian religious leadership in present-day Nigeria in advancing a sustainable transformational development agenda, but also the crucial challenges that this leadership still faces in meeting such an agenda.

\section{PREVAILING POLITICAL AND ECONOMIC CHALLENGES IN POST-MILITARY NIGERIA}

In this section the ongoing challenge of sustainable transformational development in present-day Nigerian society is discussed by specifically taking account of two broad areas: political governance and economic development. The main focus here is to critically but briefly state the ongoing challenges that impede the attainment of sustainable transformational development in Nigeria. We reiterate that sustainable transformational development is understood in this article as the process of profound and durable positive change in the spiritual, psychological, moral, social, economic, political, institutional, environmental and technological spheres of the Nigerian society. In evaluating the impediments to the attainment of sustainable transformational development, attention will particularly be focused on the Obasanjo and Yar'adua administrations, which effectively marked the beginning of the post-military or democratic era.

\section{Political governance}

The political governance of Nigeria that commenced on 29 May 1999 under the leadership of President Olusegun Obasanjo introduced the beginning of a new era in the political history of this country. This new era is termed the 'post-military' or 'democratic' era. Political governance occupies a central 
position in the Nigerian development discourse, both in the national and the international arenas. The concept of governance refers to the use of political power to manage a nation's public affairs and to shape its economic and social environment in line with perceived notions of public interest and societal progress (Nkom 2000:75). Based on Steve Nkom's definition of governance, good governance could therefore imply the use of political power by political leaders to manage the affairs of a nation effectively and to shape the economic and social environment in the interests of and to advance the progress of the entire nation. Ejeviome Otobo (2004:101-121), in turn, has pointed to the importance of political governance in the development agendas of both Nigeria and Africa as a whole. According to Otobo, three facts underscore the importance of political governance. Firstly, poor governance of states is a key hindrance to economic reform and growth. Secondly, with the persistent failure of development policies in Nigeria and subSaharan Africa, economists and development practitioners are viewing ineffective governance as contributing to such failures. Thirdly, political governance defines the context in which the other two major forms of governance-economic and corporate governance - are practised (Otobo 2004:101).

Scholars argue that despite some achievements by political leaders in post-military Nigeria, major deficiencies in certain key areas remain. This notably pertains to the inconsistencies in electrical power generation and supply, the Niger Delta oil exploitation crisis, the sporadic and lacklustre crackdowns on corruption, election rigging and Islamic militancy. At the same time, the dismal state of the manufacturing sector, the deplorable state of public schools, hospitals and roads and the huge unemployment indices could be identified as further worrisome aspects that do not reflect well on the eight years of Obasanjo's democratic rule and sadly endured under the leadership of Umaru Musa Yar'Adua, Obasanjo's successor (Eneh 2011:34; Marcellus 2009:205-206; Power 2008:69).

In judging President Yar'Adua's attempt to eradicate poverty and underdevelopment, the Nigerian newspaper Financial Standard reported in 2009 that the Poverty Eradication Council (PEC) that he headed could not achieve anything tangible towards the alleviation of poverty in Nigeria (Financial Standard 2009:6). Jonathan Power (2008:69) and Onyedika Agbedo (2010:12) likewise attributed the failure of Yar'Adua's poverty-alleviation initiatives to corrupt leadership and financial institutions such as banks, whose leaders were involved in shady financial deals involving money laundering and the embezzlement of public funds deposited in their banks. We may conclude, then, that from Obasanjo's leadership (1999-2006) to that of Yar'Adua (2007-2010), Nigeria's political leadership by and large failed to make adequate use of their political power to initiate good leadership and policies that would have contributed towards the attainment of sustainable transformational development.

\section{Economic development}

The post-military or democratic Nigerian economy is basically neo-colonial capitalist, dependent and largely dominated by primary or extractive production. It may be regarded as neocolonial capitalist because the major investors in the Nigerian economy include transnational corporations (TNCs) such as Shell, Chevron, Coca Cola, Toyota, May and Baker, and Unilever. The challenge inherent in an economy that is neo-colonial capitalist is that such an economy is in the hands of powerful foreign companies and their agents, and the usual practice is that those resources that are generated in the process of production are usually exported by those foreign owners to their home countries for the benefit of reinvestment and development (Onyekpe 2004:135-136).

The Nigerian economy is dependent in the sense that the level of production is often influenced by the dynamics and behaviour of the metropolitan economies, structured to supply these metropolitan economies with raw materials at very low prices and to serve as a market for their industrial manufactures (Onyekpe 2004:135; Shao 2001:23). Among the major economic development programmes worth mentioning in the postmilitary era is the National Economic Empowerment and Development Strategy (NEEDS). NEEDS was a 'home-grown' poverty-reduction, medium-term strategy derived from the country's long-term goal to reduce poverty and generate wealth and employment. It focused on four key strategies: reforming the way government and its institutions work; growing the private sector; implementing a social charter for the people; and re-orienting the people towards an enduring African value system (Nwokoma \& Nwokoma 2010:102; Marcellus 2009:203205).

The score card, when assessing NEEDS, which represented one of the most strategic economic development programmes in Nigeria from 1999 to 2010, is not encouraging. Commenting further on NEEDS and the policies that came into existence in the wake of its implementation, scholars conclude that quite a number of its objectives and anticipated reforms such as professionalism and enhanced efficiency in service delivery were hardly achieved. The immediate outcome of the reforms in most of the sectors was retrenchment of the workforce. As a result of the implementation of NEEDS, the scheme succeeded in creating more unemployment than the number of unemployed it set out to reduce. The total dilapidation of basic infrastructure and policy inconsistencies further worsened the employment situation in the labour-abundant Nigerian economy (Nwokoma \& Nwokoma 2010:110-111; Marcellus 2009:206; Oni 2005:6, 9).

We may well maintain that although political and economic institutions in contemporary Nigeria have made attempts to transform the Nigerian socio-political and economic contexts, sadly, profound and durable positive change in the spiritual, psychological, moral, social, economic, political, institutional, environmental and technological spheres of the Nigerian society remain elusive. It has therefore become pertinent to explore the crucial role of leadership as both a causal and redeeming factor in social transformation.

\section{THE CAUSAL AND REDEEMING FACTOR OF LEADERSHIP}

Whilst the actions and inactions of socio-political, economic and religious leadership may have contributed considerably to 
the on-going social challenges in African societies, leadership in all facets of the same societies should nevertheless be seen as a major means through which these societies can be transformed (Belshaw et al. 2001:3-6; Wolfensohn \& Carey 2001:vii). For lack of space this section will not address the different theoretical concepts of intellectual, political, state and religious leadership and their differences and interrelatedness. The focus here is to address the importance of leadership in the social transformation of African societies. We maintain that whereas there exist demarcations in academic discourses on intellectual, socio-political, economic and religious leadership in social transformation in European and North American contexts (Zuidervaart 2013:246), in Africa in general and Nigeria in particular, these delineations do not exist in the daily operation of society (Mbiti 1999:177).

Nigerians, like other Africans, view life holistically and, as such, the socio-political, intellectual, economic and religious dimensions of life are intertwined (Kunhiyop 2008:226). In the same vein, the influences of leadership from socio-political, economic and religious spheres inform each other both positively and negatively (Agbiji \& Swart 2013). It is for these reasons that leadership from these quarters is inevitable in the achievement of social transformation. In this regard, the focus now falls on both the causal and redeeming roles of leadership within the African and Nigerian contexts as a foundation for deeper consideration and exploration.

\section{The African perspective}

The attainment of political independence for African countries has been credited to African intellectuals and leaders in their respective countries, including, inter alia, Nnamdi Azikiwe (Nigeria), Kwame Nkrumah (Ghana), Julius Nyerere (Tanzania), Leopold Senghor (Senegal) and Nelson Mandela (South Africa). The efforts of these leaders have had a major positive impact not only on their own countries but, to a large extent, have also influenced the entire African continent (Agbiji 2012:41). Although the hope of the masses that their political independence would translate into economic independence is still far from being realised, Lual Deng (1998:141-146) has argued that this was not the fault of the generation of intellectuals and leaders who had fought for independence but rather that of the following generation. Deng emphasises that it is essential that the attainment of African development - a second independence - be the prerogative of contemporary African intellectuals, researchers, policy analysts and other types of leaders.

According to Deng, the state is the hub of sustainable development on which the other key elements such as agriculturally-led economic growth, social stability and ecological harmony all depend. In view of the key role that the state plays in most African countries, including Nigeria, it would therefore be impossible to side-line political leadership, as a prominent representation of the state, from development initiatives, if any meaningful development progress is ever to be achieved (Deng 1998:235). Unfortunately, however, it needs to be re-emphasised at this point that poor leadership in Africa has repeatedly dashed the hopes of the masses.
Oladele Omosegbon, focusing on the importance of economic intelligence, has remarked on the need for objectivity on the part of African intellectuals and advisers (leaders) in their choice of an economic path for their countries. Although he supports the acceleration of Africa's development through diversification, he maintains that challenging issues such as corruption, civil strife and bad governance - recurrent factors in African nations such as Nigeria, Kenya, Zimbabwe, Zambia, South Africa and many others - should be taken into consideration. In his opinion, African nations would do better by forming strong collaborative relationships between themselves than following the current trend of collaborating with the powerful nations of the Northern hemisphere (Omosegbon 2010:55). Scholars argue that leadership is key to the social transformation of African nations including Nigeria, and seldom in African history has thoughtful, credible leadership been more needed in the social transformation of African societies than it is needed today (Gumede 2014:1; Shao 2001:24). The point being stressed here is the pertinent role of leadership in the profound processes that are required for the social transformation of contemporary African societies.

\section{Nigerian perspective}

Whereas the important role of an unjust global economic order and other contributory factors to the problem of poverty and underdevelopment in Nigeria should not be underestimated, poor leadership should by and large be held responsible for the lack of sustainable transformational development in Nigeria. Chinua Achebe (1983:1) once asserted that the problem with Nigeria is simply a failure of leadership. Affirming Achebe's view on Nigerian leadership, Dele Seteolu (2004:74) has argued that the Nigerian state is governed by a predatory political class that has given rise to political corruption and underdevelopment. In the same vein, Ozoemenam Mbachu (1997:57-58) asserted that the malaise of poor leadership is not a new development in Nigeria but a challenge that has continued to live on, unconquered and disheartening. Such poor leadership has displayed incompetence and selfishness, and shown itself as incapable of satisfying the yearnings and aspirations of Nigerians. Unfortunately, because leadership has much to do with influence, the prevailing type of leadership tends to be replicated in its followers. In support of this position, Achebe (1983:10) noted that Nigerians are unavoidably what they are because their leaders are not what they should be. Mbachu (1997:59) agrees that whatever forms of behaviour the leaders engage in often tend to be reflected in the behaviour of the followers. This may seem like an over-exaggerated comment on leadership, but it is difficult to contest. Mbachu further substantiates his position by arguing that every society, whether authoritarian, dictatorial or democratic, needs committed leaders for its well-being.

The centrality of leadership in any society has long been established in political theory, which argues that society is divided into a few who have power (leaders) and the many who do not (followers) (Mbachu 1997:58-59). A leader has the capacity to navigate between the good and the just and between wisdom and consent. At the same time he/she should also be able to be flexible and principled (Lanre-Abass 2008:117). 
Leaders innovate, focus on people, develop and inspire trust, have a long-term perspective, show originality and challenge the status quo. Leaders guide, direct, motivate, influence, and make choices that enable their followers to contribute to the success or positive transformation of the entity they lead (Ukaegbu 2007:162). Sustainable transformational development is about processes of profound and durable positive change in the spiritual, psychological, moral, social, economic, political, institutional, environmental and technological spheres of the Nigerian society. Accordingly, the inability of Nigerian leaders to initiate and sustain profound changes in these spheres largely accounts for the elusiveness of sustainable transformational development in Nigeria (Egharevba \& Chiazor 2012:2; Olowu 2011:68; Agba 2010:16).

It is thus not an overstatement to argue that leadership is a core issue in Nigerian development as in many other African countries. Accordingly, it is our argument that Christian religious leadership likewise has a responsibility to rise to the challenge of addressing the scarcity of credible leadership in Nigeria so as to be able to engender sustainable transformational development. Most of the leaders in Nigeria identify with both the church and with other religious entities. Nigeria, for example, boasts a large Christian population which is engaged on a daily basis at different levels in Nigerian society (Olowu 2011:75; Oladipo 2001:222). This implies that a wellmobilised Christian fold with the desirable leadership and development ideology could effectively contribute towards the socio-economic and political transformation of the nation. The challenges of development in Nigeria persist and require deeply grounded solutions.

\section{ELEMENTS OF A REAPPRAISAL:CHRISTIAN RELIGIOUS LEADERSHIP ENGAGEMENT IN POST-MILITARY NIGERIAN SOCIETY}

With the discussion so far providing important background, we now turn our attention in this section and in the next to what we have indicated in the introduction is our main objective in this article: to move, on the basis of a recent literature and empirical exploration, towards a reappraisal of how the Christian religious leadership (Christian clergy and other Christian leaders who occupy leadership positions in denominational and ecumenical church settings but are non-clergy) is beginning to exert itself as a force for sustainable transformational development in present-day Nigerian society - i.e. most specifically in the postmilitary or democratic era.

\section{Establishment of the Christian Association of Nigeria (CAN)}

In terms of a relevant historical orientation, we may well remind ourselves of the role of Christian missionaries from the inception of Christianity in Nigeria in fostering a particular Christian influence and leadership. Their efforts were carried out mainly within the ambit of welfare and social services (Agbiji 2012:115-117), although this also extended to the establishment of institutions such as schools, hospitals, courts and publishing facilities (Aye 1987:168-170). Furthermore, many of the missionaries worked closely with the colonial administration and, in some instances, some of them played dual roles both as missionaries and administrators (see Proctor 2000:4561). Unfortunately emergent indigenous Christian religious leadership was neither enabled nor encouraged to follow suit because of the missionaries' disinclination to engage with the locals on 'secular issues' (Musa 2009:27-28; Aye 1996:1-27). Against this background, a significant development on the way to a socially and politically more engaged indigenous Nigerian Christian religious leadership took place when church leaders agreed on 27 August 1976 to form the Christian Association of Nigeria (CAN) (CAN 2010:1).

The formation of CAN, the largest ecumenical body in Nigeria and Africa (CAN 2010:1), significantly marked the unfolding of what has today undoubtedly become the 'most powerful Christian voice in Nigeria' (Mbachirin 2004:655). Despite the fact that the various church denominations in Nigeria engage in social issues in a variety of ways through their leaders and structures, CAN and its constituent blocs have become the most viable platform through which Christian religious leaders address social issues in Nigeria. The constituents of CAN reflect a conglomeration of groups inclusive of all the various denominations in Nigeria, from the national to the local level. These groups of churches that constitute CAN are also called 'blocs of CAN'. They include the Catholic Secretariat of Nigeria (CSN), Christian Council of Nigeria (CCN), Christian Pentecostal Fellowship of Nigeria and Pentecostal Fellowship of Nigeria (CPFN/PFN), Organisation of African Instituted Churches (OAIC), and Tarrarya Ekkelisiyar Kristi a Nigeria and Evangelical Church of West Africa (TEKAN/ECWA) (CAN 2010:4).

In collaboration with CAN and its constituent bodies, Nigerian church leaders are now engaging in Nigerian social discourse and activities through organisations such as the Nigerian InterReligious Council (NIREC), African Forum on Religion and Government (AFREG), Forum for Righteousness in Governance (FRIG), Congress on Christian Ethics in Nigeria (COCEN) and Save Nigeria Group (SNG). In addition, Christian religious leaders under the auspices of CAN are today collaborating with government to alleviate poverty and fight corruption. Whilst the engagement of church leaders with NIREC effectively represents the component of inter-religious dialogue, their involvements with AFREG, FRIG, COCEN and SNG relate to their advocacy and collaborative initiatives with government and civil society. In our view, it is these modes of social engagement on the part of the Christian religious leadership that now portrays it as a force for the initiation and sustenance of processes of profound durable changes in the spiritual, moral, psychological, sociopolitical and economic spheres of society herein referred to as sustainable transformational development. In the sections that follow these engagements are further discussed under the following themes: inter-religious dialogue, advocacy and collaboration.

\section{Impetus on dialogue and advocacy as tools for national cohesion}

According to the Guidelines on Dialogue with People of Living Faiths and Ideologies of the World Council of Churches (WCC), 'dialogue means witnessing to our deepest convictions, whilst 
listening to those of our neighbors' (WCC 1979:16). Lending his voice to the explanation of the concept of dialogue and its implications, John Onaiyekan, Catholic Archbishop of Abuja and formerly President of CAN and co-chairperson of NIREC, asserts that 'dialogue is perhaps the best way to describe what we understand by management of our religious diversities' (Onaiyekan 2010:7).

Within the above frame of understanding, in Nigerian society recognition of the importance of dialogue has been given special impetus by the perennial challenge of Islamic fundamentalism, which has brought about colossal destruction of human lives and property worth billions of Naira across the country. It is therefore to the credit of Nigerian Christian religious leaders, under the auspices of CAN, that they took the initiative to engage in dialogue with Islamic leaders through various fora including NIREC (Nigerian Inter-Religious Council) for the sake of the socio-political and economic development of Nigerian society (CAN 2010:15; Abubakar 2010:1; America 2004:6; CAN 2004:2).

Moreover, Christian religious leaders operating under the auspices of CAN are of the view that 'the most important political duty which CAN often performs is its warning and prophetic function' (CAN 2010:13). We are of the belief that it is this 'warning and prophetic function' that could play an important advocacy role in the transformation of Nigerian society. Church leaders in Nigeria are in the main engaged in advocacy through communiqués, press releases and messages from both the pulpit and the mass media. The statements relate to Nigerian socio-economic and political issues (Agbiji 2012:128; CAN 2012; Williams 1988:11). Other matters of concern in advocacy include religion, ethics and poverty (Minchakpu 1998:72; CAN 1988:9-12). Christian religious leaders' advocacy is aimed at transforming Nigerian society through Christian ethical virtues, which also envisions church leaders as the repositories of such virtues through which not only the faithful but also Nigerian society as a whole could be influenced (Salifu 2008:195-196; Minchakpu 1998:72).

Besides their role in religious dialogue and advocacy, Christian religious leaders have shown a positive attitude towards collaborative initiatives with other institutions such as the Nigerian government and civil society groups.

\section{Collaboration with the state and civil society sector}

Anna Nieman (2010:41) has commented meaningfully that collaboration and partnership formation are essential elements of social development practice, with collaboration representing 'the relationships of stakeholders pooling resources in order to meet objectives that neither could meet individually'. The field of education in particular constitutes one of the crucial areas that CAN and indeed the Christian church has been consistent in seeking collaboration with government. From its inception in 1976, CAN has always felt very strongly that a crucial part of its mission is to be the watchdog of the type of education that Nigerian children are receiving (CAN 2010:11; Onaiyekan 2010:33; CAN 1988:49).
According to John Onaiyekan (2010:33), education and health are historically the classical areas of social engagement by religious bodies, especially by the Christian churches. It is thus not surprising that a number of churches own educational institutions ranging from crèches to universities across the country. The health sector, as already mentioned, is another area of traditional collaboration between the church and the state that dates back to the missionary era. The Christian Health Association of Nigeria (CHAN), which constitutes the health care arm of CAN aims to provide quality health care at a subsidised rate (CAN 2010:11). Christian denominations are also themselves engaged in the provision of numerous health care services (Agbiji 2012:134,135).

Yet, in addition to these traditional areas of collaboration, Nigerian Christian religious leaders and their churches are increasingly also showing a willingness to engage in an emerging, broader level of collaboration. This significantly not only includes collaboration with the state but also with the broader civil society sector in actions that are more pointedly directed at the fight against the disturbing issues of poverty and corruption.

Indeed, animportantincentivetowards such wider collaboration was initiated when the Obasanjo administration, under the auspices of the National Poverty Eradication Programme (NAPEP), established its Promise Keeper Programme (PKP) to collaborate with religious institutions in combating poverty. The programme involved a loan scheme that entailed that government would equally match the monetary contributions of religious organisations. This amount would then be made available to such organisations as a revolving loan through which it could give loans to its members for investment purposes towards economic empowerment. This programme has been rated as one of NAPEP's most successful programmes (NAPEP 2013).

In turn, the collaboration between church leaders and an NGO such as the African Forum on Religion and Government (AFREG) may be traced back to the efforts of church leaders in July 2006. These leaders, under the auspices of the nongovernmental organisation Integrity Advocates, conceived the notion of convening an 'All African Conference on Religion, Leadership and Good Governance' (Okoye 2009:2). AFREG's vision is to create a platform for African leaders of integrity who would commit themselves to the positive transformation of the continent. Such transformation could occur through institutionalising a culture of good governance for the purpose of effectively tackling the problems of corruption, poverty and underdevelopment in Africa (Okoye 2009:2).

The fact that CAN has collaborated with AFREG has to a large extent shaped and deepened the approach and scope of church leaders with regard to a more relevant engagement in socio-political issues, especially in the Nigerian context. This collaboration also led to the formulation of what is now known as the 'Nigerian Christian Creed on Governance', an ideological framework for the engagement of both church leaders and the entire Christian community in governance. As a result of this and other similar initiatives such as the Forum 
for Righteousness in Governance (FRIG), church leaders were able, for the first time, to meet with the major presidential aspirants of political parties who were Muslims, to discuss their attitudes towards issues that are important to the development of Nigerian society (FRIG 2007; Okoye 2009:2). In addition, CAN has now created the office of the National Directorate on National Issues aimed at addressing socio-political and economic issues including collaboration with Independent Corrupt Practices and Other Related Offences Commission (ICPC), an anti-corruption agency established by the federal government to fight corruption (Okoye 2009:1-6).

In what could rightly be considered as a new dimension of social engagement, in a more recent development the leadership of the church became involved in protests against the government, through the activities of Pastor Tunde Bakare of the Later Rain Assembly, ${ }^{2}$ under the aegis of the Save Nigeria Group (SNG) (Thisday 2010:1, 5). This group is a people's movement that contributed significantly to the transformation of Nigerian society in 2010, during President Yar'Adua's health crisis $^{3}$ and the National Assembly electoral reforms. ${ }^{4}$ Through organised protests and rallies, Nigeria was delivered from a leadership vacuum and anarchy, and credible leadership was restored in the form of the national electoral body and the Federal Executive Council.

\section{COMPLEMENTARY CLAIMS FROM AN EMPIRICAL EXPLORATION}

The results of the empirical research presented here are drawn from the first author's qualitative research data collected between April 2010 and March 2011 as part of his doctoral study (Agbiji 2012). The aim of the qualitative research was to explore the engagement of Christian religious leaders in development related activities in post-military Nigeria from 1999 to 2010. Open-ended questionnaires were issued to serving and former national leaders of the Christian Association of Nigeria (CAN), whilst the same questionnaires were also issued to leaders of each of the ecumenical church blocs of CAN. Twenty-two religious leaders eventually participated in the empirical study (see Agbiji 2012:162-270).

Coding was used in order to conceal the identities of the respondents and to manage the data. Instead of using the names of the respondents, the designation ' $\mathrm{P}$ ' meaning 'person'

The Later Rain Assembly is a Pentecostal Church in Lagos founded by Pastor Tunde Bakare.

In 2010 President Yar'adua was critically ill and was flown out of the country to Saudi Arabia for medical treatment. His long absence from the country generated a lot of tension. He eventually died the same year.

The Federal Executive Council and the Nigerian National Assembly initiated electoral reforms in 2010 in response to a popular demand by the Nigerian masses to change the then leadership of the National Electoral Commission led by Prof. Maurice Iwu. Amongst other changes, the reforms led to the removal of Iwu and the appointment of Prof. Athahiru Jega, who supervised the 2011 national elections. and a number were used to differentiate between the various respondents. Coding was particularly useful in categorising the responses of the respondents for the purpose of making sense of the data in accordance with what is required in qualitative research (Gibbs 2007:38). In an effort to determine the degree of social engagement of Nigerian Christian religious leaders in the social transformation of Nigerian society, two questions were asked. The first question sought a better understanding of what the actual contribution of the Christian religious leadership to the Nigerian society is in the post-military era. The second question in turn was aimed at obtaining a better understanding of the extent to which such contribution signified a new way of addressing the challenges of poverty and underdevelopment in Nigeria on the part of the Christian religious leadership.

An initial assessment of the social engagement of Christian religious leaders was carried out on the basis of the literature study. The aim of the empirical assessment of religious leaders' social engagement was to complement the insights that were gained from the literature study. The responses elicited by the two questions revealed the respondents' own perception of the main areas of social engagement of Christian religious leaders in present-day Nigerian society. The areas identified by them were advocacy, ecumenism, dialogue, moral development, economic empowerment, education, social services, social protest and leadership development.

Respondents were of the opinion that Christian religious leaders have served the Nigerian post-military context through various forms and means of advocacy. This included, inter alia, pronouncements by Nigerian church leaders through the medium of ecumenical bodies such as CAN, CCN, PFN and CSN against corruption, poverty and violence. Yet, whilst ecumenical forums such as CAN have served as a noticeably 'strong voice for the poor and the masses, irrespective of their religious affiliation' (P18, also $\mathrm{P} 2)$, another respondent (P8) emphasised the fact that some religious leaders have also used their own pulpits as a medium for advocacy. In the words of this respondent: 'Church leaders have always denounced bad governance, corruption and poverty through their sermons, which have often served as calls on government to be responsive to the plight of the masses.'

Some respondents argued that church leaders' advocacy had a positive impact on the democratic dispensation through the way in which they pointed to government measures that could be taken to improve the welfare of Nigerians. One such respondent was $\mathrm{P} 12$, who claimed: 'Church leaders have contributed in the last ten years of democracy by advising the government on various measures to improve the welfare of the population, such as the establishment of skills acquisition centres.' However, other respondents were less affirmative and felt that there was significant scope for religious leaders to improve their advocacy role. One respondent $(\mathrm{P} 15)$ pointed to religious leaders' limited use of the pulpit, as well as their 'ignorance of biblical dogma', whilst another (P10) suggested in greater detail that

[c]hurch leaders should be passionately conscious about their environment. They should be able to notice where 
there are injustices and speak up against all forms of injustice. They should be able to take constructive steps to bring about a balance between the mission of care and spirituality. They should learn to teach the poor "how to fish rather than give them fish'. They should discourage all forms of laziness, creatively establish transparent leadership and inculcate the habit of leadership by example. They should consciously build in developmental projects as an integral part of mission.

Respondents ( $\left.\mathrm{P}_{4}, \mathrm{P}_{15}, \mathrm{P} 19\right)$ agreed that one of the achievements of church leaders on the ecumenical platform was the formation of the Christian Association of Nigeria (CAN). Whereas the church benefits from its ecumenical endeavours, Nigerian society as a whole also shares in these benefits. This position was put forward by P8, who argued that 'ecumenical leaders help in building unity among Christians of different denominations, which in turn contributes towards bringing peace to the country'. However, whilst the church and Nigerian society at large have benefited from the existing ecumenical relations, respondents have raised concerns regarding the attitudes of some religious leaders towards ecumenism. Two such respondents were $\mathrm{P} 3$ and $\mathrm{P} 2 \mathrm{O}$, who respectively remarked:

Iam sorry to say, from experience, that the focus of Christian leaders on the Ecumenical Association is dwindling and out of focus. Ecumenism involves the theology of sharing God's gift but today the churches have lost the image of koinonia and are engrossed in denominationalism ( $\left.\mathrm{P}_{3}\right)$.

Experience has shown that neglect of the ecumenical imperative in the Christian community in Nigeria is a great handicap for the church to work effectively in the areas of socio-political and economic justice (P2O).

These two respondents $\left(\mathrm{P}_{3}\right.$ and $\left.\mathrm{P}_{2} \mathrm{O}\right)$ therefore strongly felt that there was a need for a renewed strengthening of ecumenical ties among churches in Nigeria for the sake of ecclesial and larger societal wellbeing. In sharp contrast, however, other respondentswere of the opinion thatNigerianChristian religious leaders have in fact made important social contributions to Nigerian society in the area of fostering religious dialogue among Christians and other religious traditions such as Islam. One such vital contribution has been the establishment of the National Inter-Religious Council (NIREC) in collaboration with the state and the Supreme Council of Islamic Affairs. In this regard respondents noted that Christian religious leaders played a vital role in the 'formation of NIREC by the government to foster dialogue and peace between different religions' (P17) and by doing so have contributed towards 'making the society peaceful' (P14).

For a number of respondents, Christian religious leaders also had to be given credit for the way in which they contributed towards the strengthening of the moral fibre of Nigerian society. In this regard one respondent pertinently referred to 'the instilling of moral values in the members of Nigerian society by church leaders' (P5), whilst others similarly made claims about how Christian religious leaders have served as the conscience of society by 'supporting the nation morally and spiritually'
(P11), by acting as 'as architects and preachers of honesty' (P5), and by bringing 'Biblical virtues to bear on the polity' (P1).

Yet from another angle some respondents felt strongly about Christian religious leaders' contribution to grassroots economic empowerment. Thus for one respondent (P6) Christian religious leaders in Nigeria could be associated with 'a variety of projects that are geared towards the promotion of agriculture, self-employment and self-reliance'. However, in as much as the leaders of the mainline churches were known to have been concerned with projects in the missionary era and afterwards, another respondent (P11) spoke more decisively about the importance of the newly established churches and their leaders and how they are increasingly 'taking a centre stage in the economic empowerment of their members for the good of society'. Similarly, another respondent (P9) also alluded to this development by referring to a new engagement of Pentecostal churches in social transformation through projects of economic empowerment:

The socio-political and economic participation of the churches in the development of Nigeria was left to the orthodox [mainline] churches. However, the tyranny of the military juntas, since 1983, awoke the Pentecostals to unparalleled activism in those sectors for liberation (P9).

However, a significant number of respondents replied that the greatest contribution of church leaders and churches to Nigerian society has been in the field of education. This opinion was expressed by respondents $\mathrm{P}_{1}, \mathrm{P} 4, \mathrm{P} 5, \mathrm{P} 6, \mathrm{P} 9, \mathrm{P} 11$, $\mathrm{P}_{14}, \mathrm{P}_{15}, \mathrm{P} 18, \mathrm{P} 19, \mathrm{P} 21$ and $\mathrm{P} 22$, with respondent $\mathrm{P} 6$ arguing more specifically that such engagement by the churches entailed both the 'introduction and growth of formal education through church educational institutions' and respondent P11 commending the churches for establishing universities that today functioned as 'safe havens against ... [Nigeria's] cultravaged public universities'. ${ }^{5}$

On a critical note, however, two respondents (P16 and P19) expressed their concern about what they perceived as a trend whereby church-owned educational institutions were increasingly becoming unaffordable to poorer people in Nigeria. For P16 this had in fact led to the situation where ' $(\mathrm{t})$ he larger majority [of churches] capitalise on the underdevelopment and poverty to further impoverish the masses' and where, as a result, 'the self-sufficient training of the old church leaders' no longer existed. P19 also alluded to this trend by recommending: 'Establish schools that are affordable to the poor.'

\footnotetext{
5 The issue of cultic activities refers particularly to armed groups such as Buccaneers, Ku-Klux Klans, Pyrate Confraternities and other groups that are responsible for violent activities in Nigerian universities. These groups and their activities have not only contributed to insecurity in public educational institutions, but also to a decline in educational standards. Cult members are usually distracted from their studies as they often abandon their studies for militant and criminal activities within and outside the university environment. When this happens, they resort to threatening lecturers to pass them even when they fail the courses they enrol for in the university.
} 
In line with what could be learned from our exploration of the literature (as discussed in the previous section), a number of respondents $\left(\mathrm{P}_{4}, \mathrm{P}_{5}, \mathrm{P} 6\right.$ and $\left.\mathrm{P}_{18}\right)$ continued by likewise emphasising the crucial role of churches and church leaders in the field of service delivery. Whilst for one respondent ( $\left.\mathrm{P}_{5}\right)$ the provision of various forms of education strictly also belonged to this field, another respondent ( $\mathrm{P} 18)$ emphasised how 'provision of health care through church-owned health institutions' had to be recognised as 'a prominent area of engagement in the past and in contemporary Nigerian society' (P18). Furthermore, according to respondents $\mathrm{P} 4$ and $\mathrm{P} 6$, churches also stood out as providers of social services 'through relief and welfare schemes', especially during times of 'inter-communal conflicts, religious riots and natural disasters'.

In addition to the Christian religious leaders' advocacy role through the medium of communiqués and the pulpit, one respondent $(\mathrm{Pg})$ pointed to their role as well as that of Christians in general in protest action against the Nigerian government. In this regard this respondent particularly upheld the example of the Save Nigeria Group (SNG), which was 'largely a Christian initiative ... supported by Christian followers'. Yet, similar to respondent $\mathrm{P} 9$, a number of other respondents (P7, P8 and $\mathrm{P} 10$ ) likewise supported the idea that it was important that both the religious leaders and the faithful had to raise their level of protests in favour of social transformation in Nigerian society. Respondent $\mathrm{P} 10$ in particular made this point clear by stating:

If honest Christian leaders would arise and form serious pressure groups within and outside the national boundaries, if the leaders appreciate that they are answerable to God for what happens to the country even after they expire, then the Nigerian nation will experience transformation. If we have leaders who love the country above themselves and their immediate family, then the political and economic change so much desired in Nigeria would come.

Finally, one respondent $(\mathrm{P} 4)$ regarded it as important that leadership training and development were being promoted by church leaders through leadership foundations such as Lux Terra. This respondent observed as follows:

Some church leaders are already doing something to solve our problem, which has been leadership. There is a leadership foundation - Lux Terra - being established by Rev. Fr. George Ehusani for the training of future leaders. ${ }^{6}$

\section{SYNTHESISING REFLECTION: CONSIDERING THE ACHIEVEMENTS AND PREVAILING CHALLENGES}

In this article the two areas of political governance and economic development were identified from the start as central

The Lux Terra Leadership Foundation is a leadership resource outfit and training facility founded by Rev. Fr. George Ehusani. Its purpose is to expose leaders and potential leaders to the dynamics of purposeful and visionary leadership. The offices of the Foundation are located in Abuja but its activities are implemented all over Nigeria. to the challenge of sustainable transformational development in present-day post-military Nigeria. We argued that from Obasanjo's leadership (1999-2006) to that of Yar'Adua (20072010) the political leadership in Nigeria by and large failed to make adequate use of their political power to initiate good leadership and policy-making.

Our evaluation of the NEEDS strategy - which represented the most strategic economic development programme in Nigeria from 1999 to 2010 - likewise suggested that the economic fortunes of Nigerians were not profoundly transformed. In fact, we argued that Nigerians were facing worse economic conditions in the wake of the reforms brought about by NEEDS.

Our contextual analysis led us to reinforce an argument about the causal and redeeming factor of leadership in the achievement of positive social transformation both in Nigerian and in African society at large. We then proceeded towards the main focus of our article, namely to make a first contribution on the basis of a literature and empirical exploration - towards a reappraisal of the way that the Christian religious leadership in present-day Nigeria is showing new potential as a mobiliser for sustainable transformational development in this society.

Our discussion of the literature and empirical exploration highlighted various areas, forms or modes of engagement that could be taken as relevant to the challenge of sustainable transformational development in present-day Nigerian society. On the basis of this exploration, we now want to close this article with the following synthesising reflection on what we consider as the most important achievements to date by the Christian religious leadership in present-day Nigeria in advancing a sustainable transformational agenda, but also the crucial challenges that this leadership still faces in meeting such an agenda.

1. Since advocacy surfaced as a common theme both in the literature and empirical exploration, we may conclude that it ranks as potentially and actually one of the more prominent forms of social engagement of the Christian religious leadership in present-day Nigeria. This approach to the social challenges in Nigeria clearly yielded some results in the past and holds the potential to achieve even more in future. Yet we want to acknowledge the opinions of some respondents in the empirical exploration that there may still be significant scope for improvement in this area. At the same time, we also want to maintain that advocacy is a powerful means through which socio-political and economic challenges may be addressed, and that in this regard the level of advocacy of Christian religious leaders has not yet reached its full potential, particularly when one takes into consideration the numerous challenges Nigerians still face. For this reason, it is essential that religious leaders go beyond news releases, communiqués and sermons in their advocacy and become involved in additional dimensions of advocacy, which include mass rallies and campaigns, lobbying of policy-makers, public lectures, utilisation of the mass media, responsible protest actions and social network activities. In addition, the scope of such advocacy should be further broadened to include 
a genuine promotion of gender justice and the wellbeing of people with disabilities, animals and the environment.

2. Despite the critical comments from some respondents in the empirical exploration, our exploration importantly suggests that the establishment of the Christian Association of Nigeria (CAN) by Christian religious leaders was a major move in the right direction and, since the founding of CAN, the churches in Nigeria have kept on forging the path of unity and dialogue. In particular, it may be recalled that the formation of the National Inter-Religious Council (NIREC) by the Obasanjo administration had been initiated by Christian religious leaders in pursuit of one of the objectives of CAN, namely to promote understanding, peace and unity among the various peoples and strata of society. A further objective of NIREC, which is to create a permanent and sustainable channel of communication and interaction in order to promote dialogue between Christians and Muslims in Nigeria, is in alignment with the stated position of CAN. Undoubtedly, therefore, Nigeria's Christian religious leadership deserves credit for the achievement of both interfaith and intra-faith dialogue in present-day Nigeria. Although there are still tensions between the Christian and Islamic faiths, the commitment of many Christian religious leaders, in collaboration with government and certain Islamic leaders, has noticeably assisted in quelling religious tensions and in the process reducing religious violence in Nigeria. In a multi-religious and multi-ethnic society such as Nigeria, peace-building remains indispensable indeed to the achievement of meaningful development. ${ }^{7}$

3. Moral values are essential to the development and wellbeing of societies, especially in Africa, where many countries are facing the menace of corruption. Despite the fact that Bolatito Lanre-Abass (2008:123-124) has argued that the absence of a morally sound leadership in Nigeria may, in part, be attributed to the failure of religious leaders who ought to be the bastions of moral values in society, Nigerians continue to look up to their religious leaders - not least those of the Christian persuasion - as role models and repositories of high moral standards. Thus, although certain criminal acts have been associated with some professed Christian religious leaders in the recent past, such as the murder case of Rev. King, ${ }^{8}$ Christian and other religious leaders are in the public eye still seen as

In recent times, however, a new dimension of religious violence has taken the form of terrorism through the medium of the Islamic sect known as Boko Haram. The presence of this sect and it militant attitude towards any form of Western education remains a huge concern to Nigerian society and a serious threat to the achievement of sustainable transformational development.

Rev. King was the Overseer of the Christian Praying Assembly based in Ajao estate, Lagos. His real name is Rev. Emeka Ezeugo, alias Rev. King. He had been on death row over the murder of one of his church members, Ann Azuh. role models ${ }^{9}$ who could contribute and are contributing towards sanitising Nigerian society of its low moral standards. This was a belief also shared by a number of the respondents from the empirical exploration, as we have indicated.

4. Whereas leadership training has often featured in a number of church programmes, an initiative such as the founding of Lux Terra - which, as we have noted, is a socio-political leadership training centre established by a religious leader ${ }^{10}$ - is a new development in Nigeria. Initiatives such as this surely have much to offer towards the mentoring and development of competent socioreligious, political and economic leadership for Nigerian society and even for other African societies facing similar leadership challenges. Yet such political socialisation that goes beyond the mere allocation of values (Mbachu 1997:57-65) may still be a major missing link in the mindset of many Nigerian Christian religious leaders. One of the arguments by a respondent in the empirical exploration quoted earlier, namely that church leaders are bringing 'Biblical virtues to bear on the polity', is hardly tenable when one considers, for instance, the scope and extent of corruption in Nigerian society. However, our discussion in this article suggests that Nigeria's Christian religious leadership has in recent times been making gradual inroads into the political and economic realm. Christian religious leaders should be encouraged to sustain this momentum and to initiate sound ethical values in the public domain, where they are now increasingly engaging as politicians and entrepreneurs. In addition to - but also girded by - the ethical values they promote, it is through their direct participation in the political and economic realm that they could make a significant contribution to the ideals of sustainable transformational development.

5. It is commendable, as one respondent in the empirical exploration observed, that Pentecostal churches in Nigeria are today moving to the forefront of ecclesial social engagement through projects of economic empowerment. However, whilst projects may have an ameliorating effect with regard to the economic and social hardship experienced by church members and by Nigerians in general, it should also be noted that such projects are far too few to create the desired impact of sustainable transformational development (cf. Elliot 1987; Swart 2006). In addition, the financial costs of certain projects and the required infrastructure may be too much for many, if not most, churches to cope with. Such projects and their infrastructure may include electrical power generation and distribution, paved highways, and mechanised farming and storage facilities, which require market trends that would be favourable to sustained production. But it is

$9 \quad$ John Mbiti's (1999:177) assertion that where traditional rulers (leaders) are found in African societies, they are the divine symbol of their people's health and welfare is similar to the belief which many Nigerians still hold today about religious leaders. 
also possible that such projects may distract the church from channelling its energies towards the more important issues that are the cause of economic and socio-political injustice. Instead of a dominant focus on projects, such redirecting of energies calls for a far more active, critical and knowledgeable engagement on the level of economic and policy discourse contributing to the ideological and practical framework of sustainable transformational development.

6. Throughout Nigeria the people have benefited enormously from the educational institutions that had been established by the missionaries, but also afterwards when church leaders in Nigeria took over those institutions from the missionaries. Most of the Nigerian elite, including Muslims, have been products of the missionary or church schools. Successive Nigerian governments have recognised the commitment of the Christian religious leadership and their churches to education. However, the initial trend whereby church schools were affordable for many Nigerians is fast disappearing, as respondents in the empirical exploration have suggested. Many church schools, especially those owned by the new generation churches, are becoming increasingly unaffordable for the poor, some of whom contributed their meagre resources to the establishment of these schools in the hope of their children receiving an education. As disturbing as the new trend of expensive church schools may be, especially in the light of the poor educational standards of stateowned educational institutions in Nigeria, this trend does not invalidate the important, on-going contribution of Christian religious leaders and their churches to the education of the Nigerian population.

7. The provision of social services in the form of hospitals, clinics, other forms and instances of medical care, and certain activities aimed at promoting peace in traditional societies, can be said to be one of the important preserves of Christian religious leaders in Nigeria. Yet, as we have highlighted in our discussion, the way in which Nigeria's Christian religious leadership has, in addition to these traditional areas of involvement, in recent times also shown a willingness to partner with the state and institutions from civil society to empower the poor, combat corruption and promote good governance, is equally commendable and should continue. But perhaps most significantly, we have noticed how Christian religious leaders are today engaging in the Nigerian socio-political domain through organisations such as the African Forum on Religion and Government (AFREG), Forum for Righteousness in Governance (FRIG), Congress on Christian Ethics in Nigeria (COCEN) and the Save Nigeria Group (SNG). The awareness campaign among the faithful regarding politics and the screening of political contestants has shown that Christian religious leaders are gradually beginning to take their place in shaping the socio-political domain. Accordingly, the dividends of such engagements are beginning to show in the political terrain, which is now witnessing the direct participation of the Christian religious leadership in politics. ${ }^{11}$ The uniqueness of this development does not lie in the exceptional performance of the religious leaders now involved in political governance and active politics, but in their courage to venture into politics and political governance. This signifies a considerable shift from the historic mode of engagement through charity-oriented activities and social services and the non-participatory, a-political legacy of missionary Christianity in Nigeria.

8. We consider that we have provided sufficient evidence in this article to justify our reappraisal of how Nigeria's Christian leadership is showing new potential as a force for sustainable transformational development. This does not detract the fact that there is still considerable scope for further reorientation. Not least amongst the prevailing challenges, there is a need to cultivate an even stronger ecumenical spirit among the country's churches and denominations, to create an even stronger willingness on the part of the ecclesial community to collaborate with groups from civil society and the other faiths, and to an even deeper honing of knowledge and skills to engage competently with actors from the public and economic sectors. But above all, there is also an important need for the country's Christian religious leaders to develop an even sounder theological base to enable both themselves and the faithful to engage meaningfully in the public domain.
11 Christian religious leaders are today venturing into active politics in Nigeria. Prominent examples include Rev. Jonah Jang (Executive Governor of Plateau State under the People's Democratic Party), Rev. Jolly Nyame (former Governor of Taraba State under the People's Democratic Party), Pastor Chris Okotie (Presidential aspirant under the Fresh Democratic Party) and Pastor Tunde Bakare (VicePresidential aspirant under the All Nigerian Peoples' Party). 


\section{REFERENCES}

Abubakar, M.S., 2010, 'You and your Muslim neighbour', Paper presented at a seminar of the National Executive Committee (NEC) of the Christian Association of Nigeria (CAN), Abuja, 20 March.

Achebe, C., 1983, The trouble with Nigeria, Heinemann, London.

Agba, M.S., 2010, 'Combating corruption for sustainable developmental growth in Nigeria: Exploring the paradigm of divine option', International Business and Management 1(1), 16-21.

Agbedo, O., 2010, 'Senate Committee indicts NAPEP leadership for fraud', The Guardian, 18 December, 12.

Agbiji, O.M., 2012, Development-oriented church leadership in post-military Nigeria: A sustainable transformational approach, PhD dissertation, Stellenbosch University, Stellenbosch. http://hdl.handle.net/10019.1/71734.

Agbiji, O.M. \& Swart, I., 2013, 'Historical sources of Christian religious leadership ideology: Implications and challenges for social transformation in post-military Nigeria', Studia Historiae Ecclesiasticae 39(1), 221-246.

America, 2004, 'Nigerian bishops plead for peace and dialogue', America: The National Catholic Review, 7-14 June, 6, viewed 24 January 2011, from http:// business.highbeam.com/410107/article-1G1-119186151/nigerian-bishops-plead-peace-and-dialogue.

Aye, E.U., 1996, 'The foundations of Presbyterianism among the Calabar clans: Qua, Efik, Efut', in O.U. Kalu (ed.), A century and half of Presbyterian witness in Nigeria, 1846-1996, pp. 1-27, Ida-Ivory Press, Lagos.

Aye, E.U., 1987, Presbyterianism in Nigeria, Wusen Press, Calabar.

Belshaw, D. Calderisi, R. \& Sugden, C., 2001, 'Introduction', in D. Belshaw, R. Calderisi \& C. Sugden (eds.), Faith in development: Partnership between the World Bank and the churches of Africa, pp. 3-6, Regnum, Oxford.

Christian Association of Nigeria (CAN), 1988, 'Communique of 2nd General Assembly', in A.O. Makozi \& G.J.A. Ojo (eds.), Religion in a secular state: Proceedings of the Second Assembly of the Christian Association of Nigeria, pp. 48-50, CAN, Abuja.

Christian Association of Nigeria (CAN), 2004, Constitution of the Christian Association of Nigeria, CAN, Abuja.

Christian Association of Nigeria (CAN), 2010, Brief story of the Christian Association of Nigeria, CAN, Abuja.

Christian Association of Nigeria (CAN), 2012, 'Christian Association of Nigeria gives final call to Federal Government on violence against Christians', viewed 7 February 2014, from http://cannigeria.org/christians-association-of-nigeriagives-final-call-to-federal-govt-on-violence-against-christains/.

Deng, L.A., 1998, Rethinking African development: Towards a framework for social integration and ecological harmony, Africa World Press, Asmara.

Egharevba, E.M. \& Chiazor, A.I., 2012, 'Political corruption and national development in Nigeria', viewed 5 January 2015, from http://www.ameppa.org/ upload/corruptio\%20in\%20nigeria.pdf.

Elliot, C., 1987, Comfortable compassion? Poverty, power and the church, Hodder \& Stoughton, London.

Eneh, O.C., 2011, 'Nigeria's vision 20:2020: Issues, challenges and implications for development management', Asian Journal of Rural Development 1(1), 21-40.

Financial Standard, 2009, 'Addressing Nigeria's Chronic Poverty Index, 3 September, 6 .

Forum for Righteousness in Governance (FRIG), 2007, 'Leadership 2007: Who is next?', Report and recommendations of the Forum for Righteousness in Gover- nance Steering Committee to the church in Lagos and Nigeria for the purpose of the 2007 General Elections, FRIG, Lagos.

Gibbs, G., 2007, Analyzing qualitative data, Sage, London.

Gumede, V., 2014, 'Thought leadership, thought liberation, and critical consciousness for Africa's development and a just world', Unpublished inaugural professorial lecture presented at the University of South Africa, Pretoria, South Africa, 19 March.

Kunhiyop, S.W., 2008, 'The challenge of African Christian morality', in Z. Chinne (ed.), Service with integrity: The Christian in the Nigerian project, pp. 211-244, The ECWA Goodnews Church, Kaduna.

Lanre-Abass, B., 2008, 'The crisis of leadership in Nigeria and the imperative of a virtue ethics', Philosophia Africana 11(2), 117-140.

Marcellus, I.O., 2009, 'Development planning in Nigeria: Reflections on the National Economic Empowerment and Development Strategy (NEEDS) 2003-2007', Journal of Social Sciences 20(3), 197-210.

Mbachirin, A., 2004, 'Review: Church and state: The Nigerian experience. By John Chidi Nwafor', Journal of Church and State 46(1), 654-655.

Mbachu, O.I., 1997, 'Leadership and accountability in Nigeria', in C.A. Ndoh \& C.E. Emezi (eds.), Nigerian politics, pp. 57-65, CRC Publications, Owerri.

Mbiti, J.S., 1999, African religion and philosophy, Heinemann, Oxford.

Minchakpu, O., 1998, 'Nigeria: Church leaders refocus on ethics', Christianity Today 42(3), 72 .

Musa, D., 2009, Christians in politics: How can they be effective? Africa Christian Text Books, Bukuru.

National Poverty Eradication Programme (NAPEP), 2013, 'Status report on Promise Keeper Programme', viewed 10 September 2013, from http://www. napepnigeria.org/Programmes/PromiseKeeper.aspx.

Nieman, A., 2010, 'Churches and social development in South Africa: An exploration', in I. Swart, H. Rocher, S. Green \& J. Erasmus (eds.), Religion and social development in post-apartheid South Africa: Perspectives for critical engagement, pp. 37-43, SUN Press, Stellenbosch.

Nkom, S.A., 2000, 'Culture, empowerment and local government with reference to North Western Nigeria', in A. Adedeji \& B. Ayo (eds.), People-centred democracy in Nigeria? The search for alternative systems of governance at the grassroots, pp. 73-85, Heinemann, Ibadan.

Nwokoma, N.I. \& Nwokoma, N.A., 2010, 'Appraising employment and export-led industrialisation in post-reform Nigeria', in D. Seck \& S. Boko (eds.), Back on track: Sector-led growth in Africa and implications for development, pp. 99-113, Africa World Press, Trenton.

Okoye, W., 2009, 'The church in mission and transformation', Speech delivered at the 'African Forum on Religion 2: The church in mission and transformation', Limuru, Kenya, 18-21 August.

Oladipo, J., 2001, 'The role of the church in poverty alleviation in Africa', in D. Belshaw, R. Calderisi, \& C. Sugden (eds.), Faith in development: Partnership between the World Bank and the churches of Africa, pp. 219-236, Regnum, Oxford.

Olowu, D., 2011, 'Faith-based organisations and development: An African indigenous organisation in perspective', in G. Ter Haar (ed.), Religion and development: Ways of transforming the world, pp. 55-80, Columbia University Press, New York.

Omosegbon, O., 2010, 'The role of institutional factors in the modelling of economic growth and in policy formulation in Africa', in D. Seck \& S. Boko (eds.), Back on track: Sector-led growth in Africa and implications for development, pp. 37-58, Africa World Press, Trenton.

Onaiyekan, J., 2010, 'Dividends of religion in Nigeria', Unpublished public lecture 
presented at the University of Ilorin, Ilorin, Nigeria, 12 May.

Oni, S. I., 2005, 'Nigeria's transport infrastructural development: An integral part of National Economic Empowerment and Development Strategy (NEEDS)', viewed 5 January 2015, from http://www.siiv.net/site/sites/default/files/Documenti/bari2005/191.pdf.

Onyekpe, J.G.N., 2004, 'Issues in development: Nigeria', in S. Odion-Akhaine (ed.), Governance: Nigeria and the world, pp. 133-147, Panaf Press, Lagos.

Otobo, E.E., 2004, 'Contemporary external influences on corporate governance: Coping with the challenges in Africa', in B. Onimode (ed.), African development and governance strategies in the 21st century, pp. 101-121, Zed Books, London.

Power, J., 2008, 'Forward Nigeria', World Policy Journal 25(2), 69-74.

Proctor, J.H., 2000, 'Serving God and the empire: Mary Slessor in South-Eastern Nigeria, 1876-1915', Journal of Religion in Africa 30(1), 45-61.

Salifu, S.L.S., 2008, 'The Christian and nation building', in Z. Chinne (ed.), Service with integrity: The Christian in the Nigerian project, pp. 187-202, The ECWA Goodnews Church, Kaduna.

Seteolu, D., 2004, 'The challenge of leadership and governance in Nigeria', in S. Odion-Akhaine (ed.), Governance: Nigeria and the world, 70-78, Panaf Press, Lagos.

Shao, J., 2001, 'Alleviating poverty in Africa', in D. Belshaw, R. Calderisi, \& C. Sugden (eds.), Faith in development: Partnership between the World Bank and the churches of Africa, pp. 19-30, Regnum, Oxford.

Swart, I., 2006, The churches and the development debate: Perspectives on a fourth generation approach, SUN Press, Stellenbosch.

Thisday, 2010, 'Protesters demand to see Yar'Adua', 10 March, 1, 5.

Ukaegbu, C.C., 2007, 'Leadership fatalism and underdevelopment in Nigeria: Imaginative policymaking for human development', Philosophia Africana 10(2), 161-182.

Williams, C.O., 1988, 'General Secretary's report', in A.O. Makozi \& G.J.A. Ojo (eds.) Religion in a secular state: Proceedings of the Second Assembly of the Christian Association of Nigeria, pp. 10-12, CAN, Abuja.

Wolfensohn, J.D. \& Carey, W., 2001, 'Forward', in D. Belshaw, R. Calderisi, \& C. Sugden (eds.), Faith in development: Partnership between the World Bank and the churches of Africa, pp. vii-viii, Regnum, Oxford.

World Council of Churches (WCC), 1979, Guidelines on dialogue with people of living faiths and ideologies. Geneva: World Council of Churches.

Zuidervaart, L., 2013, 'Critical transformations: Macrostructures, religion, and critique', Critical Research on Religion 1(3), 243-269.

\section{Acknowledgements}

This material is based upon work supported by the National Research Foundation of South Africa (NRF) under grant number 85113. Any opinion, findings and conclusions or recommendations expressed in this material are those of the authors and therefore the NRF does not accept any liability in regard thereto.

\section{Competing interests}

The authors declare that they have no financial or personal relationship(s) that may have inappropriately influenced them in writing this article. 